\title{
Good to be Disliked? \\ Exploring the Relationship Between Disapproval of Organizations and Job Satisfaction in the French context.
}

\author{
Thomas J. Roulet \\ King's College London \\ Franklin Wilkins Building, 150 Stamford Street, \\ thomas.roulet@kcl.ac.uk
}

Forthcoming at the Journal of General Management.

\begin{abstract}
Previous research has found that a positive relationship exists between favorable perception of a firm and employees' job satisfaction: the more positively an organization is perceived, the happier are its workers. However, the current literature has overlooked the consequences of a negative corporate image, or disapproval of organizations. Building on the concept of organizational identification and the social identity literature, we fill in this gap and counterintuitively argue that employees are more likely to identify and align with their organizations when it faces illegitimate criticism. We test our hypotheses on a large-scale survey collected in France and find that perception of disapproval of an organization has indeed an adverse effect on job satisfaction. However, if employees perceive criticism as illegitimate, job satisfaction is positively impacted. This study suggests the existence of micro-level social identity reactions in case of unjustified disapprobation: employees stick together and hold the line against criticism, strengthening the collective identity and adding positive emotional value to the work experience.
\end{abstract}

Keywords: disapproval; corporate image; job satisfaction; job dissatisfaction; social identity, organizational identification. 


\section{Introduction}

Social identity theory has postulated that a positive organizational image is attractive to employees because of a phenomenon of organizational identification (Cornelissen, Haslam \& Balmer, 2007): individuals identify with their organization and this mechanism triggers a range of positive outcomes (Van Rick, 2001). Several authors have indeed empirically linked the organization's image with positive outcomes at the employeelevel. Employees are above all member of an organization and this group membership influence their corporate behavior. Helm (2012) has established that perceived external reputation has a positive impact on job satisfaction. Firms and managers have an interest in maintaining a positive image of the organization to attract the best applicants (Holtbrügge, et al. 2010) to maintain a high level of commitment (Dögl \& Holtbrügge, 2014).

However, the effect of a negative corporate image remains to be explored. Because group membership is a crucial driver of individual self-esteem (Tajfel, 1978), belonging to a negatively perceived group can be a threat to individuals' social identity. This study aims at filling in this gap by looking at the consequences of a negative corporate image on a crucial employee level outcome: job satisfaction. How is job satisfaction affected by a negative image? As illustrated by the case of Exxon after the Valdez oil spill, employees in an organization with a negative image can feel "shame, disgrace, or embarrassment" (p. 242) as well as "depression and stress" (Dutton et al. 1994: p. 240).

When their organization is disapproved of, employees are likely to distance themselves from the organization (Devers, et al. 2009), which would lead to lower job satisfaction. When insiders have to face threats to the group identity, they devaluate outsiders' appraisal (Bosmans, et al. 2016; Kreiner, et al. 2006) and ultimately counterbalance the effects of disapprobation. Beyond buffering the negative influence, external threats to the 
collective identity might lead to stronger cohesion and organizational culture (Forsyth, 1990). Believing that one's organization is in the right against the rest of the world can be a source of self-image enhancement, and thus, a source of motivation and job satisfaction. In other terms, managers of a firm facing disapproval might take the side of their organization and we can hypothesize that employees of disapproved firms will experience more pride, like people who work in a stigmatized occupation (Ashforth and Kreiner, 1999).

In this study, we formulate hypotheses regarding the effect of disapproval of organizations on job satisfaction and dissatisfaction. We test those hypotheses with a large government dataset $(\mathrm{N}=3792)$ collected in France. By focusing on the negative side of corporate image - disapproval of organizations - we show that a priori negative organizational outcomes can have positive effects at the employee level.

\section{Literature review}

A vast amount of literature has shown the positive impact of corporate image on employees' behaviors and human resource management. Employees are more likely to identify with and feel proud to work for socially responsible firms (Turban \& Greening, 1997; Cable \& Turban, 2003): the organizational identity is more attractive and can more easily be linked to the employee's own identity (Melewar, et al. 2005) because of a better personorganization fit (Yaniv, Lavi \& Siti 2010). This positive effect is conditioned on the fact that employees must be aware that their organizations is positively perceived by outsiders. Helm (2012) has for example shown that it is the perceived external reputation that directly affects job satisfaction. Kjærgaard, et al. (2011) established that in-group members derive gratification from positive media coverage of their organization. Riordan, et al. (1997) have shown a positive relationship between corporate image and job satisfaction. Overall, there is thus a consensus around the employee-level benefits of a positive corporate image. 
In some studies, corporate reputation and image have been studied as continua (Helm, 2012; Riordan et al., 1997) in which positive and negative dimensions of these constructs have not been distinguished. Does a negative corporate image have the same effect (i.e. no effect) as the lack of a positive corporate image, or does it have an opposite effect? The consequences of a negative perception of the organization remain to be explored. How would social identity theory predict the effect of a negative organizational image on employees' identity and their subsequent behaviors?

Disapproval of the firm is a negative social evaluation that expresses a 'criticism toward a firm's activities, values, and social behavior' (Vergne, 2012: 5), and occurs when social norms are violated (Roulet, 2015b) such as in the case of the arm industry (Vergne, 2012) or the nuclear industry (Piazza \& Perretti, 2015). Disapproval of an organization is a negative assessment of an organization's moral legitimacy by outsiders (Roulet, 2015a). The employees of badly reputed organizations suffer from decreased self-esteem (Cable and Turban, 2003) due to identity mechanisms (Bosmans, et al. 2016). Suspecting that someone dislikes one's behavior is enough for one to feel social disapproval (Rege and Telle, 2004): if an employee has the impression that his or her organization is disapproved of, he or she will also feel socially condemned.

Goffman's (1963) concept of courtesy stigma suggests that one can become stigmatized when associated with stigmatized people (Stenger \& Roulet, forthcoming). Considering individuals are seeking social approval (Rege and Telle, 2004), working for a disapproved organization will have adverse consequences on the relationship between the employee and his or her organization. Employees are driven by self-esteem concerns: more specifically, in the context of organizations, workers are motivated by their willingness to maintain an enhanced image of themselves (Shamir, 1991). Individuals are more satisfied with jobs that are consistent with a positive image of themselves (Korman, 1970). Inversely, if 
the job context is detrimental to self-worth, motivation is lower. Because group membership is a driver of self-esteem, a negative group image can be seen as a threat to the individual's identity (Tajfel, 1978).

One of the key individual-level outcome that can be explained by social identity mechanisms in the work context is job satisfaction (Brunetto \& Farr-Wharton, 2002). It is a particularly relevant individual level outcome to examine the effect of a negative corporate image on employees. Spector (1997) simply defines job satisfaction as the extent to which employees like their jobs and feel good about different aspects of their work. The facet approach (Spector, 1997) enables to distinguish the sources of satisfaction and the sources of dissatisfaction. As this paper focuses on a trigger of adverse consequences, it makes sense to hypothesize about the effects on the sources of both satisfaction and dissatisfaction.

Putting the previous theoretical developments in perspective, we argue that the negative perception of an organization by outsiders, as a crucial element of job context, affects job satisfaction and dissatisfaction in two ways:

Hypothesis 1: Perceived disapproval of an organization is related to (a) lower job satisfaction and (b) higher job dissatisfaction among employees.

Organizational identification comes with support for the organization (Bosmans, et al. 2016): in other terms, employees that derive pride from their membership will be more likely to side with their organization than with outsiders. Thus, when an organization is disapproved of, its employees may not necessarily consider the criticism to be legitimate. They may actually take side with their organization if they believe that disapproval is unfair or unjustified as they may justly consider that they know their organization better than external stakeholders do. Devers et al. (2009) hypothesized that the perceived responsibility 
for an illegitimate practice will increase the perceived incongruence with social norms. Consequently, outsiders and insiders might have a different perspective on who holds the responsibility for violating social norms (Clemente \& Roulet, 2015). If outsiders perceive an organization as responsible and thus disapprove it publicly, insiders might at the same time believe that their organization is innocent, or that it has had no other choice in order to survive. Employees can basically perceive the criticism as illegitimate and discards the disapproval of their organization.

External threats to a group's identity trigger defense mechanisms aimed at preserving the group members' self-esteem (Kreiner, Ashforth, and Sluss, 2006). Specifically, members of a deprecated group devaluate outsiders' judgments when those are negative, in order to maintain their pride (Ashforth and Kreiner, 1999). The appreciation of the legitimacy of the external judgments is an outcome of social creativity processes, wherein insiders build a line of reasoning in order to discount out-group perceptions (Kreiner et al., 2006). This identity defense mechanism may buffer the effects of perceived disapproval on both job satisfaction and job dissatisfaction.

Hypothesis 2: The credence attributed to the disapproval of the organization moderates its effect on job (dis)satisfaction so that when employees perceive the external disapproval of their organization as illegitimate, (a) the negative relationship between disapproval of the organization and job satisfaction is weaker (b) the positive relationship between disapproval of the organization and job dissatisfaction is weaker.

However, a consistent stream of qualitative research on stigmatized occupations, building up on social identity theory, has shown that people performing a defamed activity were able to maintain a high level of occupational esteem and pride (see Ashforth and 
Kreiner, 1999), suggesting that external negative judgments can actually have a positive effect on insiders' identity. Negative judgements can trigger even stronger organizational identification as the member of a stigmatized group is brought to defend the organization's image to preserve the self-esteem he or she derives from it (Tajfel, 1978). In this case, we argue that the effects of the perceived illegitimacy of disapproval might go beyond buffering the negative effects of disapproval on job satisfaction. Insiders are prone to dig in their heels in order to face criticism (Shymko \& Roulet, 2016) and 'socially withdraw in order to look for social validation and affirmation within their own group' (Ashforth and Kreiner, 1999: 425). Research has also shown that external threats foster group cohesion because insiders tend to stick together against outsiders (Forsyth, 1990). In addition, because disapproval generates distinctiveness, it can increase identification (Dutton, Dukerich, and Harquail, 1994).

The feeling of being in the right together with the rest of the organization and their peers - especially because the common cause strengthens organizational culture and cohesion - can have a positive impact on employees' self-concept and is thus an important motivational drive (Shamir, 1991). Ultimately, disapproval can have a positive effect on job satisfaction and negative effect on job dissatisfaction, because it implies to hold the line against the rest of the world. Thus, we formulate the following alternative hypotheses:

Hypothesis 3: The credence attributed to the disapproval of the organization can invert its effect on job (dis)satisfaction so that when employees perceive the external disapproval of their organization as illegitimate, (a) their job satisfaction increases and (b) their job dissatisfaction decreases.

\section{Method}


The data we used in this study comes from the 'Histoire de Vie' survey conducted in 2003 by the French National Institute of Statistics (INSEE) (Histoire de Vie, 2003), aimed at exploring the construction of identity in French society. This large dataset includes a comprehensive set of questions on work, as well as questions on demographics, marital information, sociability, political and religious activities, and disability. The survey was conducted through face-to-face interviews lasting 70 minutes, which were conducted in the respondents' homes. The response rate was $62 \%$. Among the 8,403 respondents, the dataset includes 3,886 professionally active individuals on which we can test the hypotheses. We removed the observations for which some variables were missing and ended up with a total of 3,792 observations. Their demographic, job, and firm characteristics are summarized in Table $1^{\mathrm{i}}$

Dependent variables: To measure job satisfaction, we used a composite approach: we aggregated a number of dummies corresponding to questions in which the respondents were asked, for each dimension of the job, whether they would definitely like to keep a given element ("yes" being 1 and "no" being 0). These elements are occupation, colleagues, schedule, salary, job status (employee or independent worker), workplace, advancement opportunities, hierarchical position, and the organization itself. These elements represent those that explain the majority of variance in job satisfaction (Kinicki et al., 2002). The job satisfaction variable is the summed composite of the responses, where higher scores indicate greater satisfaction. It ranges from 0 (not satisfied with any of these elements) to 7 (no individuals in the sample are satisfied with more than 7 elements). It is motivated by simplicity, the face validity offered by single-item measures compared to the multiple items approach (such as the one used for the Job Descriptive Index, JDI; P. C. Smith, Kendall, and Hulin, 1969), as well as the significant correlation of single-item with multiple-item measures 
for each facet (Wanous, Reichers, and Hudy, 1997; Nagy, 2002). Internal consistency reliability is satisfactory (the average of the 8 Cronbach's alphas are above 0.70 ).

In addition to this composite measure of job satisfaction, the survey provides us with another dependent variable. The respondents were asked whether 'at work, the motives for satisfaction (respectively dissatisfaction) prevail' or if 'the motives of satisfaction and dissatisfaction balance each other'. We modeled a dummy equal to 1 if the motives of satisfaction prevail. This measure is similar to the global single-item dichotomous measure of job satisfaction used by Scarpello and Campbell (1983) as an alternative to multiple-item measures, and to a global single-item measure of job satisfaction.

Because the level of job satisfaction is "a function of the different satisfactions and dissatisfactions a person experiences with respect to different aspects of work" (MalinowskaTabaka, 1987: 454), We distinguished job satisfaction and job dissatisfaction and built consistent hypotheses across those two dependent variables. The items for which employees might report no satisfaction are not necessarily the same than those for which they report dissatisfaction. In addition, distinguishing the sources of job satisfaction and dissatisfaction limits the biases implied by self-censorship (Oshagbemi, 1999). Although consistent results can be expected across the two dependent variables, the magnitude of the effects may diverge. To measure job dissatisfaction, we use another sequence of questions in which individuals answered, whether they would like to change the same elements as mentioned in the job satisfaction items (occupation, colleagues, schedule, salary, job status, workplace, advancement opportunities, hierarchical position, organization). We added the seven dummies to obtain a score from 0 (not dissatisfied with any of those elements) to 7 (dissatisfied with the highest number of elements, considering there are no individuals that are dissatisfied with more than 7 elements). The internal consistency reliability (mean of Cronbach's alphas $=$ 0.65) is acceptable. Finally, we used the global item to build an additional dichotomous 
variable equal to 1 when respondents acknowledge that 'at work, motives for dissatisfaction prevail'.

Independent variables: To build the independent variables, we used items from the survey in which the respondents were asked how they react 'when [they] hear someone criticizing [their] firm or administration'. Based on this item, we built a dummy variable equal to 1 if the respondents felt that their organization was criticized and 0 if their organization was not criticized or if the individual was indifferent to the criticism. In addition, if the organization was criticized (when the previously mentioned dummy is equal to 1), the respondents had to say if the criticism seemed justified, unjustified, or 'exaggerated but sometimes justified'. This reflects the level of perceived legitimacy of the disapproval. We coded three dummies corresponding to these three responses.

\section{Insert Table 1 about here}

Control variables: We used a variety of controls such as basic demographics (sex, age, and a dummy variable corresponding to marital status), and variables related to the job and the organization (annual revenues split into 16 levels, job tenure in years, a dummy variable for type of contract - whether it is an open-ended contract, which is the most secured - , seven dummies for occupation - unskilled worker, skilled worker, technician, foreman or salesman, executive or engineer, employee, none of these -, four dummies for the type of organization - government, local authority or public organization, public company, or private company -, and five dummies for specific working conditions - unusual working hours, work on Sundays and legal holidays, work at night, business trips, and interaction with external stakeholders beyond colleagues). Considering that the primary use of this dataset was to investigate the potential issues faced by immigrants and individuals suffering from 
disabilities, and that those populations are slightly over-represented, we controlled for those characteristics by adding a dummy equal to 1 if the individual was born in France, a dummy equal to 1 if the individual was a descendant of immigrant parents, and a dummy equal to 1 if the individual suffered from a disability. In addition, to avoid multicollinearity issues, as the dummies for occupation and type of organization were mutually exclusive groups of variables, we did not include in the analysis the local authority and public organization dummy or the unskilled worker dummy.

Multicollinearity and common method bias: Although we only found moderate levels of correlation between the variables (see Table 2), we checked for multicollinearity by calculating the variance inflation factors (VIF) and the condition indices. The mean VIF was 1.74; all VIF values were below the cutoff value of 5 and the condition number was below 30 (Hair et al., 1998). Thus, multicollinearity was not a concern. The fact that a one-wave survey provides both dependent and independent variables may generate common method biases: the correlation between dependent and independent variables may be inflated (Podsakoff et al., 2003). Although measures were not self-reported (every respondent was interviewed on a personal basis by a questioner who came to his or her home), we formally assessed the impact of common method bias by running a factor analysis and used a marker variable technique (Lindell \& Whitney, 2001) revealing absence of common method bias ${ }^{1}$.

Model: The main dependent variable (job satisfaction) as well as the alternative dependent variable (job dissatisfaction) take ordinal values respectively from 0 to 7 . Their outcomes can be ranked in a meaningful sequential order, but the distance between them is

\footnotetext{
11 To run the confirmatory factor analysis (Podsakoff et al. 2003), we entered the items of the independent and control variables into a factor analysis. It extracted 7 factors with eigenvalues superior to 1 . The first factor accounted for $19.6 \%$ of the variance, while the following three accounted for a bit more than $10 \%$ of the variance. No single factor accounted for the majority of the variance. As a marker variable, we used the perception by the interviewee of the frequency of interaction with other family members. This ordinal variable has 5 levels from "once a week" to "never". The analysis shows non-significant correlations with job satisfaction $(-1.10 \%$ with the ordinal scale, $0.54 \%$ with the dichotomous measure) and with job dissatisfaction (1.70\% with the ordinal scale, $2.88 \%$ with the dichotomous measure). After adjusting for the common method variance all of the predictor-criterion correlations remained statistically significant.
} 
unknown, which violates the assumptions needed to use a linear regression model (Long and Freese, 2006). For such ordinal outcomes, ordered logit or probit regressions would be the most adapted (Long and Freese, 2006; Menard, 2001). Following Long and Freese (2006), we test the proportional odds assumption by testing the hypotheses on a generalized ordered logit (Fu, 1999) and by conducting a Brant test to see if the coefficients for each variable are consistent across the different pairs of outcomes (Brant, 1990). With the exception of the variable reflecting a neutral level of legitimacy, the results of the Brant tests show that the coefficients of the independent variables of interest do not change across the different pairs of outcomes, and we can thus conclude that the ordered logit model is perfectly valid.

\section{Results}

The means, standard deviations, and correlations are shown in Table 2. The dependent variables exhibit a low level of correlation with the independent variables. The ordinal scale of job satisfaction is moderately related to the dichotomous measure of job satisfaction $(\mathrm{r}=.18, \mathrm{p}<0.01)$, and the pattern is similar for job dissatisfaction $(\mathrm{r}=.24, \mathrm{p}<$ 0.01). The ordinal scales of job satisfaction and job dissatisfaction are, on the other hand, not related $(\mathrm{r}=.03, \mathrm{p}<0.1)$.

Insert Table 2 about here

The results of the ordered logistic regressions and the ordered log-odds regression coefficients are presented in Table 3 (models 1 to 4 look at job satisfaction as the dependent variable) and 5 (models 5 to 8 look at job dissatisfaction as the dependent variable). Models 3 , 4, 7 and 8 , look at the dichotomous dependent variables. 
Hypothesis $1 \mathrm{~b}$ predicts that disapproval is positively related to job dissatisfaction. The positive and significant $(\mathrm{p}<0.001)$ coefficients on the disapproval measure in the models using job dissatisfaction as the dependent variable supports this hypothesis. Hypothesis 1a is consistent with hypothesis $1 \mathrm{~b}$ and predicts a negative relationship between disapproval and job satisfaction. On the contrary, the positive sign on the disapproval measure $(p<0.001)$ in models 1 and 2 suggests that disapproval has overall a positive effect on job satisfaction. How can this paradoxical result be explained? The only non-significant coefficient on disapproval comes in model 3, which uses a dichotomous job satisfaction dependent variable. However, when the variable is split up into the three dummies reflecting the perceived legitimacy of the disapproval, the three coefficients are significant but exhibit different signs. This element suggests that the coefficient for disapproval is not significantly different than 0 because the effect of disapproval depends on its level of perceived legitimacy.

Hypothesis $2 \mathrm{a}$ and $2 \mathrm{~b}$ predict that the relationship between perceived disapproval of the organization and job satisfaction and dissatisfaction are weaker if the external disapproval is seen as illegitimate. Hypotheses $3 \mathrm{a}$ and $3 \mathrm{~b}$ predict that the level of perceived legitimacy of the disapproval can invert the effects, respectively, on job satisfaction and dissatisfaction. In order to test these hypotheses, the independent variable was split into three dummy variables corresponding to the perception of disapproval when it occurs. The three variables show a gradation in the legitimacy attributed by the respondent to the outsiders' criticism from a clearly justified to a clearly unjustified disapprobation. For the models looking at job satisfaction, the parameter estimate for a clearly justified criticism is negative and significant (at the $\mathrm{p}<0.1$ level when looking at the ordinal scale of job satisfaction, at the $\mathrm{p}<0.001$ level when looking at the dichotomous measure of job satisfaction). When disapproval is perceived as clearly legitimate, it does have an adverse impact on job satisfaction. For the 'exaggerated but justified' disapproval, the coefficient is positive and significant $(\mathrm{p}<0.001)$ when looking 
at the ordinal scale of job satisfaction, but negative at the $\mathrm{p}<0.05$ level when looking at the dichotomous measure. Finally, the positive sign on the 'clearly unjustified' disapproval on both models (at the $\mathrm{p}<0.001$ level) provides strong support for hypothesis 3a: when employees perceive disapproval as unfair, it actually has a positive impact on their job satisfaction. The level of legitimacy of the disapproval inverts the effect on job satisfaction. This result explains the positive relationship between disapproval and job satisfaction in models 1 and 3: only when respondents find that the criticism is legitimate does disapproval have a negative impact on job satisfaction.

In models 6 and 8, which look at job dissatisfaction as the outcome variable, the coefficients for 'clearly justified' disapproval and 'exaggerated but sometimes justified' disapproval are all positive (with significance level ranging from $p<0.001$ to $p<0.01$ ). The magnitude of the coefficient clearly suggests that a 'clearly justified' criticism has the strongest positive relationship with job dissatisfaction. This result suggests that the more legitimate is the disapproval the stronger is the relationship with job dissatisfaction, which provides support for hypothesis $2 \mathrm{~b}$. The coefficient for the 'clearly unjustified' disapproval comes up positive and non-significant. The perception of external disapproval is positively related with the identification of sources of satisfaction, but does not cancel out the sources of dissatisfaction: it simply attenuates dissatisfaction. One explanation could be that sources of satisfaction are more malleable and more easily influenced than sources of dissatisfaction (Oshagbemi, 1999).

Insert Table 3 about here

We find that the more illegitimate is the disapproval, the weaker is its positive effect on job dissatisfaction. The legitimacy of disapproval even reverses the relationship 
when solely looking at the elements reflecting job satisfaction: a clearly unjustified disapproval of the organization is positively related to job satisfaction while a clearly justified one is negatively related to job satisfaction. The results are also consistent across models: the negative binomial models and OLS regressions used as robustness checks (Menard, 2001) exhibit similar results to the ordered logit models, except for the "Clearly justified criticism" dummy in the model looking at job satisfaction. This variable is more significant in the negative binomial and OLS models.

\section{Discussion}

Social identity theory enabled us to intuitively predict a link between employees' perception of disapproval and lower job satisfaction or higher job dissatisfaction. Considering that group membership is a key driver of self-esteem for individuals (Tajfel, 1978; Tajfel \& Turner, 1979; Cornelissen et al. 2007), when a group is tainted, individuals within this group will dissociate themselves from it, experience lower organizational identification, and thus less satisfaction with the different facets of work. The effect of disapproval of the organization on employees' level of (dis)satisfaction is however a function of how legitimate this disapproval is, from their point of view. We test those hypotheses in the French context, using a government survey. France is an appropriate context to observe how employees react to the disapproval of their organizations considering the general distrust against business organizations in this country (Landier, 2005). The French business environment offers many opportunities, but the activities of private and public organizations are often debated by the media, social movements and the public opinion (Gordon \& Kingston, 1996).

Employees disdain the negative external perspectives in order to preserve the pride they get from their group membership. When an individual perceives a threat to his or her self-esteem, due to an external judgment of the organization he or she is affiliated to, the 
credit given to this external criticism has a moderating effect. If the disapproval is perceived as legitimate, the threat for one's identity is stronger, and the employees have good reasons to distance themselves from their organization to preserve their self-worth. Interestingly, we find that disapproval of the organization has overall a positive effect on job satisfaction. The perception of the external judgment can invert the effects of disapproval. Insiders not only disdain outsiders' perspectives, they also 'bunker' themselves in order to preserve their selfesteem. In other terms, organizational identification can be reinforced by the external threat.

\section{External validity and limitations}

Considering the data has been solely collected in France, it is worth discussing the external validity of this study: how generalizable are our results? As we previously discussed, France is a context in which there is usually an intense questioning of public and private organizations' activities (Gordon \& Kingston, 1996), which might explain why $65 \%$ of the respondents experience disapproval of their organizations. This percentage might be slightly higher than in other countries. However, considering the size of our sample (3 792 individuals, representative of the French population, a population that has similar characteristics compared to other major developed countries) we can easily assume that the relationship between disapproval of the organization and job satisfaction would hold in other national contexts.

One of the constraints that we experienced in this study was the use of an already collected dataset: gathering primary data would have enabled us to refine the items and to test more specific mechanisms. In particular, we had to compute the dependent variables on the basis of single-item dichotomous measures of the dimensions of job satisfaction and dissatisfaction. In addition, the main independent variables were built on a single item. Another limitation of the data is the suspicion regarding a potential selection bias. Designing 
the survey could have helped us improve the way we control for those two sources of selection bias by adding items related to the turnover intention and the conditions in which the individuals joined the organization. A second wave of survey would also have been useful to limit the presence of common method bias.

\section{Implications for practice and general management}

Our study provides practical implications for crisis management and communication. More specifically, we offer practical implications for companies that have to manage a negative image: communication directed towards employees is crucial to maintain job satisfaction in a context of external criticism of the organization. Making employees the advocates of the firm, using internal communication, can even have a positive impact on their satisfaction at work. Concretely, managers need to justify the firm's strategy and behavior internally (for example using internal newsletters or staff meetings) to prevent employees from taking the outsiders' perspective in case of disapproval of their organization. When Monsanto was facing a global backlash against GMO, the French branch put a lot of efforts justifying its social role to its employees (using GMO to fight hunger) and how it "makes their employees proud" ${ }^{2}$. Using those tools, they can recourse to impression management techniques within the organization (Khan, 2015) and not only as an interaction with outsiders.

We believe that the effect of disapproval of the organization would extend to other employees' behaviors among which some are key to the functioning of organizations. For example, we would expect to find a negative effect of disapproval of the organization on volunteerism (De Abreu, et al. 2015). Previous research has more generally shown the key importance of person-organization fit and its link with social performance (Yaniv, et al.

\footnotetext{
${ }^{2}$ See https://twitter.com/LPJofficiel/status/603995612166643712 and http://www.monsanto.com/global/fr/actualites/documents/monsanto-entreprise-ou-il-fait-bontravailler.pdf
} 
2010), and of corporate identity (Melewar, et al. 2005). Our work bridges the gap between those two arguments by showing how corporate identity is a key element of personorganization fit: a positive corporate identity will trigger organizational identification and ultimately trigger a better employee-organization fit. Managers have thus an interest in developing a positive corporate identity that can be shared among employees.

\section{Theoretical contributions}

The focus on the outcomes of a negative perception of the organization enables us to enrich this perspective with less intuitive conclusions. It is not the nature of the outsider views that matters, but more the perception of these views by employees. The concern is thus whether outsider judgments are legitimate, valid or simply relevant from the employees' perspective. While organizational prestige and image are related to positive employee-level outcomes, we argue that the source of this external assessment and its importance and relevance from the employee's point of view determines the magnitude of the effect. Misconduct can be perceived as an acceptable behavior in some institutional contexts (Roulet \& Touboul, 2015; Roulet, 2015a). As initially pointed out by Gill's concept of identity regulation (Gill, 2013), taking in account a diversity of opinions including insiders' perception of outsiders' points of view, is crucial when looking at organizational identity.

We also showed the necessity of treating positive and negative organizational image, as different constructs to better understand the antecedents and consequences of corporate identity (Melewar at al. 2005). This brings about major implications for social identity theory as it stresses the need to operationalize identity of individuals and organizations as they are perceived (Shymko \& Roulet, 2016; Stenger \& Roulet, forthcoming).

\section{Future research}


The next step would be to test the mediating and moderating effects on smaller samples to build a finer grained understanding of the social identity mechanisms at stake. Similar to previous studies (Helm, 2012; Riordan et al., 1997), the theoretical framework suggests that organizational identification mediates the relationship between organizational image (in both its negative and positive dimensions) and job satisfaction. The results suggest that organizations that are not held in high regard can actually achieve stronger organizational identification, on the condition that insiders challenge outsiders' perception. Future research could look more closely at the materialization of the bonding process as a consequence of an external attack. In addition, the differences in the results when looking at job dissatisfaction as the dependent variable suggests that the sources of dissatisfaction are less likely to be cancelled out, while sources of satisfaction can be more easily affected by elements that are peripheral to the work context. 


\section{REFERENCES}

Ashforth, B. E. and Kreiner, G. E. (1999). “"How can you do it?": Dirty work and the challenge of constructing a positive identity. Academy of Management Review, 24(3), 413434.

Bosmans, K., Mousaid, S., De Cuyper, N., Hardonk, S., Louckx, F., \& Vanroelen, C. (2016). Dirty work, dirty worker? Stigmatisation and coping strategies among domestic workers. Journal of Vocational Behavior, 92, 54-67.

Brant, R. (1990). Assessing proportionality in the proportional odds model for ordinal logistic regression. Biometrics, 1171-1178.

Brunetto, Y., \& Farr-Wharton, R. (2002). Using social identity theory to explain the job satisfaction of public sector employees. International journal of public sector management, 15(7), 534-551.

Cable, D. and Turban, D. B. (2003). The value of organizational reputation in the recruitment context: a brand-equity perspective. Journal of Applied Social Psychology, 33, 2244-2266.

Clemente, M., \& Roulet, T. (2015). Public Opinion as a Source of Deinstitutionalization: A "Spiral of Silence" Approach. Academy of Management Review.

Cornelissen, J. P., Haslam, S. A., \& Balmer, J. M. (2007). Social identity, organizational identity and corporate identity: Towards an integrated understanding of processes, patternings and products. British journal of management, 18(s1), S1-S16.

de Abreu, M. E., Laureano, R., Alwi, S. F. S., da Silva, R. V., \& Dionísio, P. (2015). Managing volunteerism behaviour. Journal of General Management, 40(3).

Devers, C. E., Dewett, T., Mishina, Y. and Belsito, C. A. (2009). A general theory of organizational stigma'. Organization Science, 20(1), 154-171.

Dögl, C., \& Holtbrügge, D. (2014). Corporate environmental responsibility, employer reputation and employee commitment: an empirical study in developed and emerging economies. The International Journal of Human Resource Management, 25(12), 1739-1762.

Dutton, J. E., Dukerich, J. M. and Harquail, C. V. (1994). Organizational images and member identification. Administrative Science Quarterly, 39, 239-263.

Elsbach, K. D. and Kramer, R. M. (1996). Members' responses to organizational identity threats: encountering and countering the business week rankings. Administrative Science Quarterly, 41, 442-476.

Forsyth, D. R. (1990). Group dynamics. Pacific Grove, CA: Brooks/Cole Publishing.

$\mathrm{Fu}$, V. K. (1999). Estimating generalized ordered logit models. Stata Technical Bulletin, $8(44)$.

Gill, M. J. (2013). Elite identity and status anxiety: an interpretative phenomenological analysis of management consultants. Organization.

Goffman, E. (1963). Stigma: Notes on the Management of Spoiled Identity. Prentice-Hall, Englewood Cliffs, NJ.

Gordon, C., \& Kingston, P. (1996). The business culture in France. Butterworth-Heinemann.

Hair, J. F., Anderson, R. E., Tatham, R. L. and Black, W. C. (1998). Multivariate Data Analysis, 5th edition. Upper Saddle River, NJ: Pearson Education. 
Helm, S. (2012). A matter of reputation and pride: associations between perceived external reputation, pride in membership, job satisfaction and turnover intentions. British Journal of Management.

He, H., \& Balmer, J. M. (2007). Perceived corporate identity/strategy dissonance: triggers and managerial responses. Journal of General Management, 33(1), 71.

Histoire de vie. (2003), INSEE, Centre Maurice Halbwachs (CMH), France.

Khan, S. (2015). Abusive supervision and negative employee outcomes: the moderating effects of intimidation and recognition. Journal of General Management, 41(1).

Kinicki, A. J., McKee-Ryan, F. J., Schriesheim, C. A., and Carson, K. P. (2002). Assessing the construct validity of the Job Descriptive Index: A review and meta-analysis. Journal of Applied Psychology, 87(1), 14-32.

Kjærgaard, A., Morsing, M. and Ravasi, D. (2011). Mediating identity: a study of media influence on organizational identity construction in a celebrity firm. Journal of Management Studies, 48(3), 514-543.

Kreiner, G. E., Ashforth, B. E., and Sluss, D. M. (2006). Identity dynamics in occupational dirty work: integrating social identity and system justification perspective. Organization Science, 17(5), 619-636.

Landier, H. (2005). Divorce à la Française, Comment les Français Jugent les Entreprises. Dunod, Paris.

Lindell, M. K., and Whitney, D. J. (2001). 'Accounting for common method variance in cross-sectional research designs'. Journal of Applied Psychology, 86(1) 114-121.

Long, J. S., and Freese, J. (2006). Regression models for categorical dependent variables using Stata. College Station, Tex.: StataCorp LP.

Malinowska-Tabaka, E. (1987). Complex measures of job satisfaction/disatisfaction among professionals. Social Indicators Research, 19 (4), 451-473.

Menard, S. (2001). Applied logistic regression analysis (No. 106). SAGE Publications, Incorporated.

Melewar, T. C., Karaosmanoglu, E., \& Paterson, D. (2005). Corporate identity: concept, components and contribution. Journal of General Management, 31(1), 59-81.

Nagy, M. S. (2002). Using a single-item approach to measure facet job satisfaction. Journal Of Occupational and Organizational Psychology, 75(1), 77-86.

Oshagbemi, T. (1999). Overall job satisfaction: how good are single versus multiple-item measures?. Journal of Managerial Psychology, 14(5), 388-403.

Piazza, A., \& Perretti, F. (2015). Categorical Stigma and Firm Disengagement: Nuclear Power Generation in the United States, 1970-2000. Organization Science, 26(3), 724-742.

Podsakoff, P. M., MacKenzie, S. B., Lee, J-Y., Podsakoff, N. P. (2003). Common method biases in behavioral research: A critical review of the literature and recommended remedies. Journal of Applied Psychology, 88(5), 879-890.

Rege, M. and Telle, K. (2004). The impact of social approval and framing on cooperation in public good situations. Journal of Public Economics, 88(7-8), 1625-1644. 
Riordan, C. M., Gatewood, R. D. and Bill J. B. (1997). Corporate image: employee reactions and implications for managing corporate social performance. Journal of Business Ethics, 16, 401-412.

Roulet, T. (2015a). Qu'il est bon d'être méchant!. Revue française de gestion, (3), 41-55.

Roulet, T. J. (2015b). "What Good is Wall Street" Institutional Contradiction and the Diffusion of the Stigma over the Finance Industry. Journal of Business Ethics. 130(2), 389402.

Roulet, T. J., \& Touboul, S. (2015). The intentions with which the road is paved: Attitudes to liberalism as determinants of greenwashing. Journal of Business Ethics, 128(2), 305-320.

Shamir, B. (1991). Meaning, self and motivation in organizations. Organization Studies, 12, 405-424.

Scarpello, V., and Campbell, J. P. (1983). Job satisfaction: are all the parts there?. Personnel psychology, 36(3), 577-600.

Shymko, Y., \& Roulet, T. (2016). When does Medici hurt DaVinci? Mitigating the Signaling Effect of Extraneous Stakeholder Relationships in the Field of Cultural Production. Academy of Management Journal.

Spector, P. E. 1997. Job satisfaction: Application, assessment, causes, and consequences. Beverly Hills, CA: Sage.

Stenger, S., \& Roulet, T. J. (Forthcoming). Pride against Prejudice? The Stakes of Concealment and Disclosure of a Stigmatized Identity for Gay and Lesbian Auditors. Work Employment \& Society.

Tajfel, H. (1978). Social categorization, social identity, and social comparison. In Tajfel, H. (ed.), Differentiation between Social Groups. Studies in the Social Psychology of Intergroup Relations. London: Academic Press, pp. 61-76.

Tajfel, H. and Turner, J. C. (1979). An integrative theory of intergroup conflict. In W. G. Austin and S. Worchel (Eds.), Social Psychology of Intergroup Relations. Monterey, CA: Brooks-Cole .

Turban, D. and Greening, D. (1997). Corporate social performance and organizational attractiveness to prospective employees. Academy of Management Journal, 40(3), 658-672.

Turban, D. B. (2001). Organizational attractiveness as an employer on college campuses: An examination of the applicant population. Journal of Vocational Behavior, 58(2), 293-312.

Van Dick, R. (2001). Identification in organizational contexts: Linking theory and research from social and organizational psychology. International Journal of Management Reviews, 3(4), 265-283.

Vergne, J-P. (2012). 'Stigmatized categories and public disapproval of organizations: a mixed methods study of the global arms industry (1996-2007)'. Academy of Management Journal.

Wanous, J. P., Reichers, A. E., and Hudy, M. J. (1997). Overall job satisfaction: how good are single-item measures?. Journal of applied Psychology, 82(2), 247.

Yaniv, E., Lavi, O. S., \& Siti, G. (2010). Person-Organisation Fit and its impact on organisational citizenship behaviour as related to social performance. Journal of General Management, 36(2). 
$\overline{-120}$ 
Table 1: Sample characteristics $(\mathrm{N}=3,792)$ and descriptive statistics for the independent variables of disapproval of the organization and legitimacy of this disapproval

\begin{tabular}{|rrrrrrr|}
\hline & Mean & SD & Min & \multicolumn{1}{c|}{ Max } & \\
Age & 40.85 & 10.40 & 18 & 81 & \\
Revenues & 9.59 & 2.49 & 0 & 16 & \\
Job tenure & 19.03 & 12.29 & 1 & 64 & \\
& & & & & & \\
Gender & $50.05 \%$ & (Male) & French nationality & $85.71 \%$ \\
Married & $56.86 \%$ & & & & & \\
\hline
\end{tabular}

\begin{tabular}{|c|c|c|c|}
\hline \multicolumn{4}{|c|}{ Job and firm characteristics: } \\
\hline \multicolumn{2}{|c|}{ Occupation } & \multicolumn{2}{|l|}{ Type of Contract } \\
\hline Unskilled worker & $7.36 \%$ & Apprentice & $0.55 \%$ \\
\hline Skilled worker & $16.82 \%$ & Intern & $0.16 \%$ \\
\hline Technician & $7.62 \%$ & Temporary Worker & $1.85 \%$ \\
\hline Foreman or Salesman & $12.13 \%$ & Fixed-Time Contract & $8.99 \%$ \\
\hline Executive or Engineer & $17.25 \%$ & Open-Ended Part-Time Contract & $76.56 \%$ \\
\hline Employee & $36.18 \%$ & Open-Ended Full-Time Contract & $11.66 \%$ \\
\hline None of the previously mentioned & $2.64 \%$ & Student-Public Servant Contract & $0.24 \%$ \\
\hline \multicolumn{2}{|l|}{ Working conditions: } & \\
\hline Unusual working hours & $38.03 \%$ & Government & $17.43 \%$ \\
\hline Work on Sundays and Legal & & Public Organization or Local & \\
\hline Holidays & $23.87 \%$ & Authority & $10.68 \%$ \\
\hline Work at Night & $15.30 \%$ & Public Company & $4.67 \%$ \\
\hline Business Trips & $15.80 \%$ & Private Company & $67.22 \%$ \\
\hline $\begin{array}{r}\text { Interaction with external } \\
\text { stakeholders }\end{array}$ & $56.28 \%$ & & \\
\hline
\end{tabular}

\begin{tabular}{|r|c|c|}
\hline & & \\
The organization is & 246 & 64.87 \\
criticized: & 0 & $\%$ \\
& & \\
The respondent is & 626 & 16.51 \\
indifferent: & & $\%$ \\
You never heard any & 706 & 18.62 \\
criticism: & & $\%$ \\
\hline & 379 & \\
& 2 \\
\cline { 2 - 3 }
\end{tabular}

$\left\{\begin{array}{r|c|c|}\hline \text { You find this criticism justified: } & 654 & \% \\ \text { You find this criticism } & & 56.59 \\ \text { sometimes exaggerated but } & 1392 & 56.59 \\ \text { sometimes justified } & & \% \\ \text { You find this criticism } & & 16.83 \\ \text { unjustified: } & 414 & \% \\ \hline\end{array}\right.$


Table 2: Descriptive statistics

\begin{tabular}{|c|c|c|c|c|c|c|c|c|c|c|c|c|c|c|c|}
\hline & & Mean & SD & 1 & 2 & 3 & 4 & 5 & 6 & 7 & 8 & 9 & 10 & 11 & 1 \\
\hline 1 & Job Dissatisfaction & -1.88 & 1.47 & 1 & & & & & & & & & & & \\
\hline 2 & Job Satisfaction & 2.30 & 1.64 & $-0.03^{* *}$ & 1 & & & & & & & & & & \\
\hline 3 & Clearly justified criticism & 0.11 & 0.31 & $-0.14 * * *$ & $-0.06^{* * *}$ & 1 & & & & & & & & & \\
\hline 4 & Exaggerated but Sometimes Justified & 0.37 & 0.48 & $-0.06^{* * *}$ & $0.08 * * *$ & $-0.26^{* * *}$ & 1 & & & & & & & & \\
\hline 5 & Clearly unjustified criticism & 0.17 & 0.38 & $0.05^{* * *}$ & $0.06^{* * *}$ & $-0.16^{* * *}$ & $-0.34 * * *$ & 1 & & & & & & & \\
\hline 6 & Gender: Male & 0.50 & 0.50 & -0.02 & 0.01 & -0.01 & 0.00 & $0.03 * *$ & 1 & & & & & & \\
\hline 7 & Age & 40.85 & 10.40 & $0.21^{* * *}$ & 0.01 & $-0.05^{* * *}$ & 0.01 & $0.06^{* * *}$ & 0.02 & 1 & & & & & \\
\hline 8 & Revenues & 9.59 & 2.49 & $0.03 * *$ & $0.11 * * *$ & $0.03 *$ & $0.19 * * *$ & 0.02 & $0.29 * * *$ & $0.15^{* * *}$ & 1 & & & & \\
\hline 9 & Job Tenure & 19.03 & 12.29 & $0.15^{* * *}$ & $-0.03 *$ & -0.02 & $0.04 * *$ & 0.00 & $-0.03 *$ & $0.47^{* * *}$ & $0.08 * * *$ & 1 & & & \\
\hline 10 & Open-Ended Contract & 0.88 & 0.32 & $-0.10^{* * *}$ & $0.09 * * *$ & $0.04 * *$ & $0.06^{* * *}$ & $0.03 * *$ & 0.02 & $0.08^{* * *}$ & $0.23 * * *$ & $0.06^{* * *}$ & 1 & & \\
\hline 11 & Employed by the Government & 0.17 & 0.38 & $0.04 * *$ & $0.03 * *$ & 0.00 & $0.19 * * *$ & 0.00 & $-0.05 * * *$ & $0.04 * *$ & $0.16^{* * *}$ & $0.10^{* * *}$ & $0.12 * * *$ & 1 & \\
\hline 12 & Employed by a Public Company & 0.05 & 0.21 & -0.02 & 0.02 & 0.00 & $0.04 * * *$ & $0.03 *$ & 0.01 & $0.04 * * *$ & $0.05^{* * *}$ & 0.02 & $0.07^{* * *}$ & $-0.09 * * *$ & \\
\hline 13 & Employed by a Private Company & 0.67 & 0.47 & $-0.14 * * *$ & -0.01 & 0.01 & $-0.19 * * *$ & -0.02 & $0.09^{* * *}$ & $-0.15^{* * *}$ & $-0.06^{* * *}$ & $-0.13 * * *$ & $0.26^{* * *}$ & $-0.52 * * *$ & -0.2 \\
\hline 14 & Married & 0.57 & 0.50 & $0.11^{* * *}$ & 0.02 & -0.03 & 0.02 & $0.04 * *$ & $0.07 * * *$ & $0.34 * * *$ & $0.10^{* * *}$ & $0.17 * * *$ & $0.08 * * *$ & 0.01 & 0. \\
\hline 15 & Skilled worker & 0.17 & 0.37 & -0.03 & 0.02 & -0.01 & $-0.10 * * *$ & 0.02 & $0.31 * * *$ & 0.01 & $-0.08 * * *$ & 0.02 & $0.03 *$ & $-0.17^{* * *}$ & -0.0 \\
\hline 16 & Technician & 0.08 & 0.27 & $-0.06^{* * *}$ & 0.01 & 0.02 & $0.03 *$ & 0.00 & $0.16^{* * *}$ & 0.00 & $0.07 * * *$ & 0.00 & $0.05 * * *$ & $-0.10^{* * *}$ & 0.0 \\
\hline 17 & Foreman or Salesman & 0.12 & 0.33 & 0.00 & $0.04 * *$ & 0.02 & $0.11^{* * *}$ & 0.02 & 0.01 & 0.02 & $0.15^{* * *}$ & $0.04 * *$ & $0.07 * * *$ & $0.17 * * *$ & 0.0 \\
\hline 18 & Executive or Engineer & 0.17 & 0.38 & $0.09^{* * *}$ & $0.04 * * *$ & $0.03 *$ & $0.16^{* * *}$ & $-0.03 *$ & $0.11 * * *$ & $0.09^{* * *}$ & $0.49 * * *$ & 0.01 & $0.10^{* * *}$ & $0.21 * * *$ & 0. \\
\hline 20 & Other Occupation & 0.03 & 0.16 & 0.02 & $-0.06^{* * *}$ & 0.00 & 0.00 & -0.01 & -0.02 & 0.00 & $-0.03 * *$ & -0.02 & $-0.14 * * *$ & -0.01 & -0.1 \\
\hline 21 & Unusual working hours & 0.38 & 0.49 & $-0.06^{* * *}$ & -0.01 & 0.00 & -0.01 & 0.02 & $0.11^{* * *}$ & -0.02 & 0.01 & $-0.05 * * *$ & $-0.09^{* * *}$ & -0.02 & -0 \\
\hline 22 & Work on Sundays and Legal Holidays & 0.24 & 0.43 & $-0.04 * * *$ & 0.02 & $0.03 *$ & $0.03 * *$ & $0.03 * *$ & $0.08 * * *$ & $-0.04 * *$ & 0.02 & $-0.05^{* * *}$ & $-0.16^{* * *}$ & -0.02 & -0.0 \\
\hline 23 & Work at Night & 0.15 & 0.36 & $-0.05^{* * *}$ & 0.02 & 0.01 & 0.03 & 0.01 & $0.18^{* * *}$ & $-0.04 * * *$ & $0.07 * * *$ & $-0.04 * *$ & $-0.07^{* * *}$ & 0.00 & -0 \\
\hline 24 & Business Trips & 0.16 & 0.36 & -0.01 & $0.07 * * *$ & -0.01 & $0.08 * * *$ & 0.03 & $0.22 * * *$ & 0.01 & $0.29 * * *$ & $-0.05 * * *$ & $0.04 * *$ & 0.02 & 0.0 \\
\hline 25 & Interaction with External Stakeholders & 0.56 & 0.50 & $-0.03 * *$ & $0.11^{* * *}$ & $0.05^{* * *}$ & $0.13^{* * *}$ & 0.00 & $-0.04 * *$ & $-0.04^{* *}$ & $0.13 * * *$ & $-0.06^{* * *}$ & 0.00 & $0.09^{* * *}$ & -0 \\
\hline 26 & French Nationality & 0.86 & 0.35 & $-0.05 * * *$ & $0.03 *$ & 0.02 & $0.11 * * *$ & 0.02 & -0.01 & $-0.06^{* * *}$ & $0.07 * * *$ & $-0.03 *$ & 0.01 & $0.07^{* * *}$ & 0.1 \\
\hline
\end{tabular}




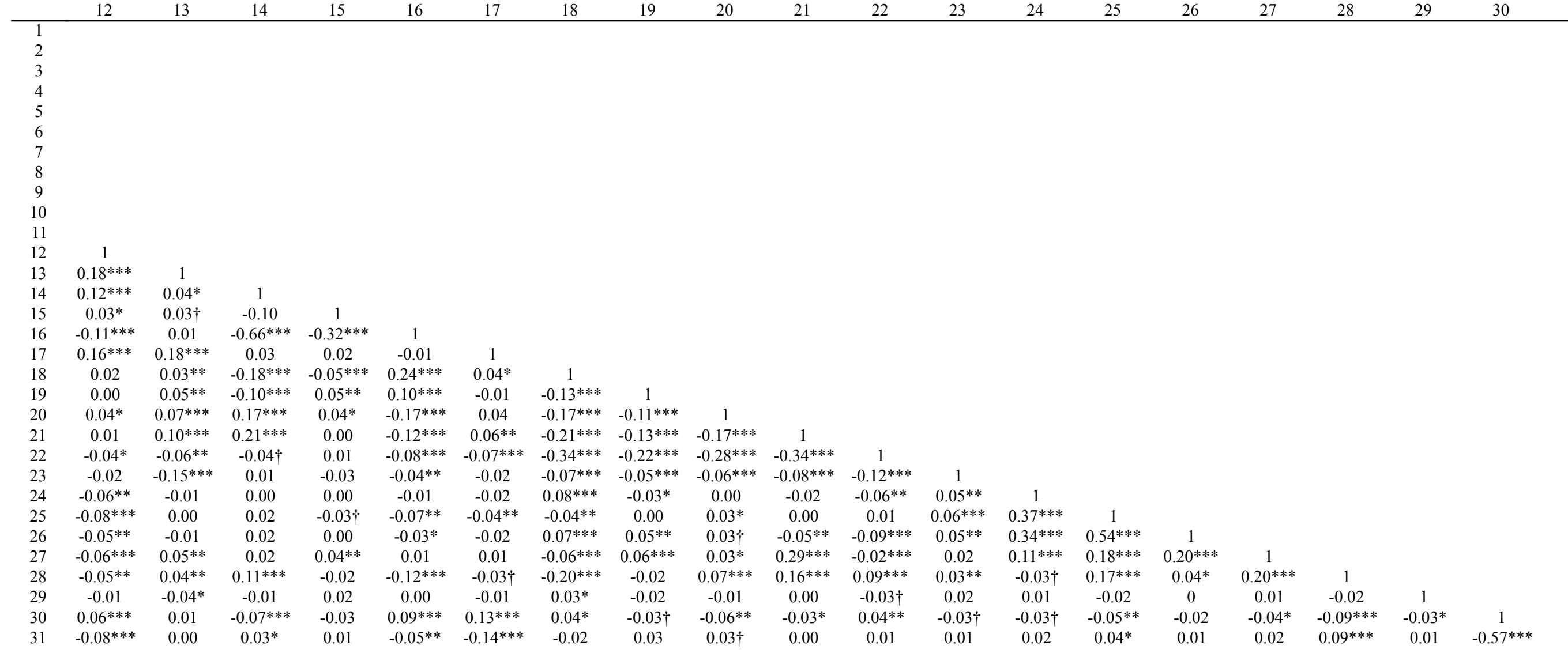

$* * * \mathrm{p}<0.001, * * \mathrm{p}<0.01, * \mathrm{p}<0.05, \dagger \mathrm{p}<0.1$ 
Table 3: Results of Ordered-Logit (Ordinal Scale of Job Satisfaction/Dissatisfaction) and Logit Regressions (Global Dichotomous Measure of Job Satisfaction/Dissatisfaction)

\begin{tabular}{|c|c|c|c|c|c|c|c|c|}
\hline \multirow{2}{*}{$\begin{array}{l}\text { DEPENDENT VARIABLE } \\
\text { VARIABLES }\end{array}$} & \multicolumn{2}{|c|}{$\begin{array}{c}\text { Job Satisfaction (Ordinal } \\
\text { variable) }\end{array}$} & \multicolumn{2}{|c|}{$\begin{array}{l}\text { Job Satisfaction (Global } \\
\text { dichotomous variable) }\end{array}$} & \multicolumn{2}{|c|}{$\begin{array}{c}\text { Job Dissatisfaction } \\
\text { (Ordinal variable) }\end{array}$} & \multicolumn{2}{|c|}{$\begin{array}{c}\text { Job Dissatisfaction } \\
\text { (Global dichotomous } \\
\text { variable) }\end{array}$} \\
\hline & (1) & $(2)$ & (3) & (4) & $(5)$ & (6) & (7) & $(8)$ \\
\hline Disapproval & $\begin{array}{c}0.23 * * * \\
(0.07)\end{array}$ & & $\begin{array}{l}-0.07 \\
(0.08)\end{array}$ & & $\begin{array}{c}0.52 * * * \\
(0.07)\end{array}$ & & $\begin{array}{c}0.48 * * * \\
(0.12)\end{array}$ & \\
\hline Clearly Justified Criticism & & $\begin{array}{c}-0.19 \dagger \\
(0.1)\end{array}$ & & $\begin{array}{c}-0.68 * * * \\
(0.12)\end{array}$ & & $\begin{array}{l}0.99 * * * \\
(0.10)\end{array}$ & & $\begin{array}{c}1.22 * * * \\
(0.16)\end{array}$ \\
\hline $\begin{array}{l}\text { Exaggerated but sometimes } \\
\text { justified }\end{array}$ & & $\begin{array}{c}0.31 * * * \\
(0.07)\end{array}$ & & $\begin{array}{l}-0.19^{*} \\
(0.09)\end{array}$ & & $\begin{array}{c}0.57 * * * \\
(0.08)\end{array}$ & & $\begin{array}{l}0.46^{* *} \\
(0.14)\end{array}$ \\
\hline Clearly Unjustified Criticism & & $\begin{array}{c}0.34 * * * \\
(0.09)\end{array}$ & & $\begin{array}{c}0.49^{* * *} \\
(0.10)\end{array}$ & & $\begin{array}{c}0.15 \\
(0.09)\end{array}$ & & $\begin{array}{l}-0.20 \\
(0.18)\end{array}$ \\
\hline Gender: Male & $\begin{array}{l}-0.13 \dagger \\
(0.07)\end{array}$ & $\begin{array}{c}-0.16 \dagger \\
(0.07)\end{array}$ & $\begin{array}{l}-0.10 \\
(0.08)\end{array}$ & $\begin{array}{l}-0.13 \\
(0.08)\end{array}$ & $\begin{array}{l}-0.02 \\
(0.07)\end{array}$ & $\begin{array}{c}0.00 \\
(0.07)\end{array}$ & $\begin{array}{c}0.14 \\
(0.13)\end{array}$ & $\begin{array}{c}0.18 \\
(0.13)\end{array}$ \\
\hline Age & $\begin{array}{l}-0.00 \\
(0.00)\end{array}$ & $\begin{array}{l}-0.00 \\
(0.00)\end{array}$ & $\begin{array}{l}-0.00 \\
(0.00)\end{array}$ & $\begin{array}{l}-0.00 \\
(0.00)\end{array}$ & $\begin{array}{c}-0.02 * * * \\
(0.00)\end{array}$ & $\begin{array}{c}-0.02 * * * \\
(0.00)\end{array}$ & $\begin{array}{l}-0.00 \\
(0.01)\end{array}$ & $\begin{array}{c}0.00 \\
(0.01)\end{array}$ \\
\hline Revenues & $\begin{array}{c}0.07 * * * \\
(0.02)\end{array}$ & $\begin{array}{c}0.07 * * * \\
(0.02)\end{array}$ & $\begin{array}{c}0.07 * * * \\
(0.02)\end{array}$ & $\begin{array}{c}0.07 * * * \\
(0.02)\end{array}$ & $\begin{array}{c}0.01 \\
(0.02)\end{array}$ & $\begin{array}{c}0.01 \\
(0.02)\end{array}$ & $\begin{array}{c}-0.07 * * \\
(0.02)\end{array}$ & $\begin{array}{c}-0.08^{* *} \\
(0.03)\end{array}$ \\
\hline Job Tenure & $\begin{array}{l}-0.00 \\
(0.00)\end{array}$ & $\begin{array}{l}-0.00 \\
(0.00)\end{array}$ & $\begin{array}{c}-0.01 * * \\
(0.00)\end{array}$ & $\begin{array}{l}-0.01 * \\
(0.00)\end{array}$ & $\begin{array}{c}-0.01 * * * \\
(0.00)\end{array}$ & $\begin{array}{c}-0.01 * * * \\
(0.00)\end{array}$ & $\begin{array}{c}0.00 \\
(0.00)\end{array}$ & $\begin{array}{c}0.00 \\
(0.00)\end{array}$ \\
\hline Open-ended contract & $\begin{array}{c}0.10 \\
(0.10)\end{array}$ & $\begin{array}{c}0.12 \\
(0.10)\end{array}$ & $\begin{array}{l}-0.16 \\
(0.11)\end{array}$ & $\begin{array}{l}-0.15 \\
(0.12)\end{array}$ & $\begin{array}{c}0.16 \\
(0.10)\end{array}$ & $\begin{array}{c}0.15 \\
(0.10)\end{array}$ & $\begin{array}{c}0.18 \\
(0.18)\end{array}$ & $\begin{array}{c}0.14 \\
(0.18)\end{array}$ \\
\hline Employed by the government & $\begin{array}{l}-0.22 \dagger \\
(0.12)\end{array}$ & $\begin{array}{c}-0.23 * * \\
(0.12)\end{array}$ & $\begin{array}{l}0.29 * \\
(0.13)\end{array}$ & $\begin{array}{l}0.30^{*} \\
(0.14)\end{array}$ & $\begin{array}{l}-0.10 \\
(0.12)\end{array}$ & $\begin{array}{l}-0.10 \\
(0.12)\end{array}$ & $\begin{array}{c}0.02 \\
(0.23)\end{array}$ & $\begin{array}{c}0.03 \\
(0.23)\end{array}$ \\
\hline Employed by a public firm & $\begin{array}{l}-0.13 \\
(0.16)\end{array}$ & $\begin{array}{l}-0.14 \\
(0.16)\end{array}$ & $\begin{array}{l}-0.08 \\
(0.19)\end{array}$ & $\begin{array}{l}-0.10 \\
(0.19)\end{array}$ & $\begin{array}{c}0.18 \\
(0.16)\end{array}$ & $\begin{array}{c}0.19 \\
(0.16)\end{array}$ & $\begin{array}{l}-0.03 \\
(0.33)\end{array}$ & $\begin{array}{l}-0.02 \\
(0.33)\end{array}$ \\
\hline Employed by a private firm & $\begin{array}{c}-0.27^{* *} \\
(0.10)\end{array}$ & $\begin{array}{c}-0.26^{* *} \\
(0.10)\end{array}$ & $\begin{array}{l}-0.24^{*} \\
(0.12)\end{array}$ & $\begin{array}{l}-0.24^{*} \\
(0.12)\end{array}$ & $\begin{array}{l}0.21^{*} \\
(0.11)\end{array}$ & $\begin{array}{l}0.21 \dagger \\
(0.11)\end{array}$ & $\begin{array}{l}0.35 \dagger \\
(0.19)\end{array}$ & $\begin{array}{l}0.34 \dagger \\
(0.19)\end{array}$ \\
\hline Married & 0.08 & 0.08 & 0.06 & 0.04 & $-0.15^{*}$ & $-0.15^{*}$ & -0.18 & -0.16 \\
\hline
\end{tabular}




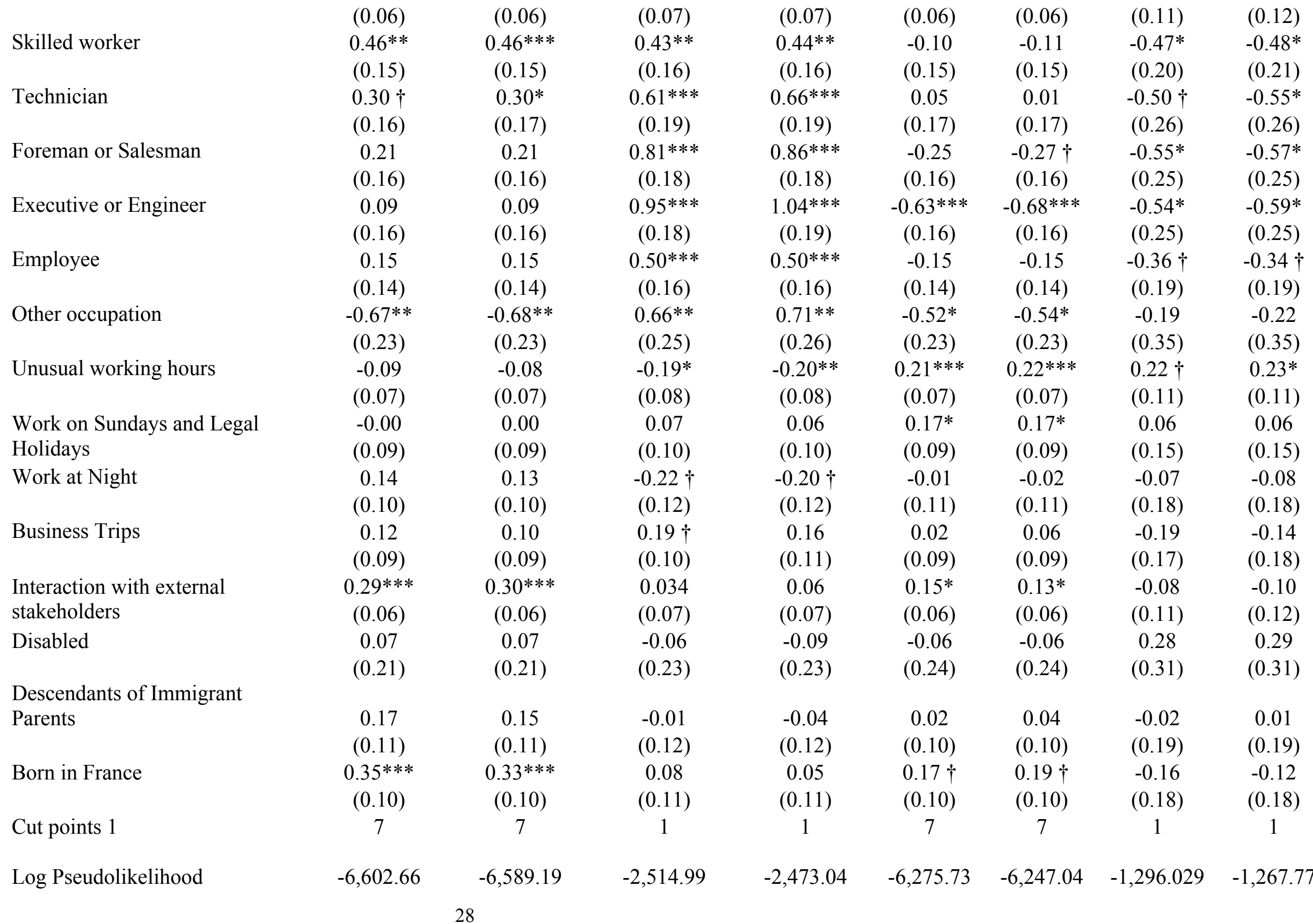




\begin{tabular}{|c|c|c|c|c|c|c|c|c|}
\hline Wald test (prob $\left.>\chi^{\wedge} 2\right)$ & $172.07 * * *$ & $198.89 * * *$ & $193.76 * * *$ & $265.82 * * *$ & $312.65 * * *$ & $376.38 * * *$ & $58.50 * * *$ & $111.15 * * *$ \\
\hline Pseudo R2 & 0.013 & 0.015 & 0.040 & 0.056 & 0.025 & 0.030 & 0.023 & 0.044 \\
\hline Observations & 3,792 & 3,792 & 3,792 & 3,792 & 3,792 & 3,792 & 3,792 & 3,792 \\
\hline
\end{tabular}

Robust standard errors in parentheses $* * * \mathrm{p}<0.001,{ }^{* *} \mathrm{p}<0.01,{ }^{*} \mathrm{p}<0.05, \dagger \mathrm{p}<0.1$ 